\title{
Formulation, Development and Evaluation of Bakery Products from Brown Rice
}

\author{
G. Gurumeenakshi ${ }^{1 *}$, N. Varadharaju ${ }^{2}$ and R. Rajeswari ${ }^{3}$
}

${ }^{1}$ Centre for Post Harvest Technology, Agricultural Engineering College \& Research Institute, Tamil Nadu Agricultural University, Coimbatore - 641003, India

${ }^{2}$ Agricultural Engineering College \& Research Institute, Tamil Nadu Agricultural University, Coimbatore - 641003, India

${ }^{3}$ CPHT, TNAU, Coimbatore, India

*Corresponding author

\begin{tabular}{|c|c|}
\hline & A B S T R A C T \\
\hline Keywords & \multirow{4}{*}{$\begin{array}{l}\text { Brown rice is whole or broken kernels of rice from which the hulls have been removed. } \\
\text { Brown rice contains a high amount of fibre. It is also contained three major components; } \\
\text { i.e., bran, germ and endosperm. The bran contains approximately } 80 \% \text { at the minerals, the } \\
\text { germ contains vitamin E, minerals, unsaturated fats, antioxidants and phytochemicals and } \\
\text { the endosperm contains protein. The trend is now marching towards health consciousness } \\
\text { and present opportunities for rice phytochemicals to find new applications in health care } \\
\text { products and in many places they started to consume partially milled rice or brown rice } \\
\text { owing to their nutritional quality. there is a need to enhance or promote the utilization of } \\
\text { brown rice requires a viable technology that would increase its storage stability, value } \\
\text { addition method that generates new food products based on brown rice. Brown rice } \\
\text { cookies were developed with the incorporation of } 50 \% \text { of brown rice to whole wheat flour. } \\
\text { The product was nutritional superior by being rich in crude fibre and minerals. }\end{array}$} \\
\hline $\begin{array}{l}\text { Bakery products, } \\
\text { Brown rice, Whole } \\
\text { wheat flour, } \\
\text { Nutritional superior }\end{array}$ & \\
\hline Article Info & \\
\hline $\begin{array}{l}\text { Accepted: } \\
\text { 10 June } 2019 \\
\text { Available Online: } \\
\text { 10 July } 2019\end{array}$ & \\
\hline
\end{tabular}

\section{Introduction}

Rice (Oryza sativa L.) originated from Southern and South Eastern parts of Asia. This is a strategically important cereal in many developing countries and is a staple food for more than 75 per cent of the world's population. Rice, wheat and corn are the most dominating plants which occupy an important place in the diet of the consumers Rice supplies food for a greater number of human beings than any other known plants and grows in over 100 countries and in every continent except Antarctica.

World's Rice production of 2010-2011 was 80.65 million tonnes, during the recent years 2011-2012 final estimates was 92.75 (million tonnes), 2012-2013 2nd advanced estimates as 90.69 (million tonnes) The production of rice in India and Tamil Nadu were about 80412.3 (in 000 tones) and 5400.4 (000 tones) respectively. (State of Indian Agriculture, 2012-2013). 
Rice is predominantly consumed in the polished form which holds good for both raw rice and parboiled rice. The degree of polishing determines its whiteness which is directly proportional to the consumer acceptability.

The complete milling and polishing that converts brown rice into white rice it destroys $67 \%$ of the vitamin $\mathrm{B}_{3}, 80 \%$ of the vitamin $\mathrm{B}_{1}, 90 \%$ of the vitamin $\mathrm{B}_{6}, 50 \%$ of the manganese, $50 \%$ of the phosphorus, $60 \%$ of the iron, dietary fibre and essential fatty acids, fully milled and polished white rice is required to be "enriched" with vitamins $\mathrm{B}_{1}$, $\mathrm{B}_{3}$ and iron (Babu et al., 2009).

Brown rice is defined as whole or broken kernels of rice from which the hulls have been removed in other words the dehusked rice. Brown rice is unpolished, whole grain rice that is produced by removing only the hull or husk using a mortar and pestle or rubber rolls. It may be distinctly brown, reddish or purplish. The embryo may or may not be left intact depending on the hulling process. It becomes milled or white rice when the bran layer is stripped off in the milling or 'whitening' process. Thus, the distinguishing factor is its unpolished feature and not the colour. It has a mild nutty flavour, chewier and more nutritious than white rice.

Brown rice contains a high amount of fibre. It is also contained three major components; i.e., bran, germ and endosperm. The bran contains approximately $80 \%$ at the minerals, the germ contains vitamin E, minerals, unsaturated fats, antioxidants and phytochemicals and the endosperm contains protein. In addition, it has been ascertained that the antioxidant levels in whole grains are higher than in white rice (Begum et al., 2000; chitra et al., 2010).

Brown rice contain good amount of carbohydrates $77.4 \mathrm{~g}$, protein $8.5 \mathrm{~g}$, fat $0.6 \mathrm{~g}$, fibre $3.5 \mathrm{~g}$, calcium $10 \mathrm{mg}$, phosphorus $280 \mathrm{mg}$, iron $2.8 \mathrm{mg}$ and thiamine $0.27 \mathrm{mg}$ and the average content of minerals $0.9 \mathrm{~g}$, riboflavin $0.1 \mathrm{mg}$ and niacin $0.4 \mathrm{mg}$ per $100 \mathrm{~g}$ (Gopalan, 2002).

The trend towards health consciousness and aging populations in many countries present opportunities for rice phytochemicals to find new applications in health care products and in many places they started to consume partially milled rice or brown rice owing to their nutritional quality.

Though the health benefits of brown rice are significant, it has to be proven still, for which extensive research has to be taken up. Any processing technology would be proven successful, if it is user friendly and highly accepted by the consumers. Enhancing or promotion of utilization of brown rice requires a viable technology for value addition which would generate new food products based on brown rice.

The presence of nutrient dense bran layer found on the surface of brown rice, makes it prone infestation by insects, microbes and the lipase enzyme released during the hulling process, catalyses the breakdown of oil in the bran layer causing rancidity. Both of these factors are responsible for the short shelf life and poor acceptability of brown rice and its products among the masses.

Thus the development of the technology for effective utilization of non wheat flour like brown rice flour may be a part of the subject of research in the field of cereal processing technology in the country. With this view, there is a need to enhance or promote the utilization of brown rice requires a viable technology that would increase its storage stability, value addition method that generates new food products based on brown rice. 
Hence a research was under taken to standardize the process for development of brown rice flour incorporated bakery foods, viz., cookies and bread and analysis of its nutritional qualities and shelf life.

\section{Materials and Methods}

\section{Materials}

\section{Paddy}

The paddy were procured from the local modern rice mill and were milled to brown rice (i.e) dehusked unpolished rice and were pulverized into brown rice flour.

\section{Raw ingredients}

The commercial refined wheat flour was purchased from flour mill. The remaining ingredients namely sugar, yeast, shortening, oil, bread improver and calcium propionate were purchased from the local market.

\section{Packaging materials}

Poly Propylene (PP) pouches with 70 gauge, 100 gauge thickness and plastic containers were purchased from the dealer.

\section{Chemicals}

The chemicals with analytical reagent (AR) or laboratory reagent (LR) or guaranteed reagent (GR) grade were purchased from the local market for analytical purpose.

\section{Glassware}

The glassware such as burette, pipette, conical flasks, and volumetric flasks, measuring cylinders, funnels, beakers, petridishes, test tubes and boiling test tubes were used for analysis in the study.

\section{Equipment}

The equipments available in the University were used in the present investigation for the development of bread and cookies (Table 1).

\section{Method}

\section{Milling of brown rice}

\section{Purchase of paddy}

The paddy free from infestation was procured from the market in bulk. They were cleaned to remove the dust, dirt, chaff and stones by winnowing and sieving. The cleaned paddy was dried at room temperature for 6 to $8 \mathrm{hrs}$, by spreading uniformly.

\section{Preparation for paddy by traditional method}

The cleaned paddy was sun dried and heaped for one hour for tempering (15\% moisture) and stored in gunny bags until milling for conversion to raw brown rice.

\section{Milling of paddy}

The paddy was cleaned to remove the dust, dirt, chaff and stones by winnowing and sieving and was milled in a local rice mill which is Qusai modernized mill. The paddy was passed through destoner to remove the left over dust, dirt, chaff and stones. Through elevator the paddy was taken to the sheller for shelling. The husk was aspirated through fan box. The brown rice and unshelled paddy were collected separately.

\section{Pulverizing of brown rice into flour}

The collected brown rice was subjected to pulverizer in order to obtain the brown rice flour. 
Development of bakery product from brown rice flour

Bakery products viz., bread and cookies and extruded product viz., vermicelli were prepared from brown rice flour and the formulation and the level of incorporation is been discussed below (Fig. 1 and 2).

\section{Formulation and preparation of cookies}

Cookies were prepared by incorporating brown rice flour with whole wheat flour from 25 to 100 per cent levels. The ingredients used in the preparation of control/standard cookies were whole wheat flour $(100 \mathrm{~g})$, powdered sugar (30g), shortening $(50 \mathrm{~g})$, baking powder $(2 \mathrm{~g})$ and corn flour $(1 \mathrm{~g})$. The functional ingredient whole wheat flour was replaced by brown rice flour at various levels of incorporation (25 to $100 \%)$. The proportion of ingredients used for the preparation of cookies is presented in the Table 2.

\section{Preparation}

The flour was sieved in a BS 60 mesh sieve. The powdered sugar and vanaspathi were mixed thoroughly and other ingredients were added.

The dough was rolled into uniform sheet of desired size (thickness of $0.6 \mathrm{~cm}$ and $4 \mathrm{~cm}$ diameter) and was cut into circular shapes using cookies cutter and baked in an oven at $210^{\circ} \mathrm{C}$ for $15 \mathrm{~min}$.

After $24 \mathrm{hrs}$, the cookies were packed in different packaging materials.

\section{Formulation and preparation of bread}

Breads were prepared by incorporating brown rice flour from 25 to 100 per cent levels of incorporation. The ingredients used in the preparation of control were whole wheat flour (100g), sugar (18g), yeast (3g), shortening $(2.5 \mathrm{~g})$, salt $(1.5 \mathrm{~g})$, water $(54 \mathrm{ml})$, calcium propionate $(0.3 \mathrm{~g})$ and bread improver $(0.2 \mathrm{~g})$. The functional ingredient whole wheat flour used in the preparation of bread was replaced by brown rice flour. The proportion of ingredients used for the preparation of bread is furnished in Table 3.

\section{Preparation}

The flour was sieved in a BS 60 mesh sieve.

The sugar and yeast were dissolved in required amount of water and kept for 10 minutes.

All dry ingredients were mixed by using yeast suspension and fat was added, mixed well and kneaded for 15 minutes.

The dough was covered with a wet cloth and kept for one hour.

The dough was knocked back and transferred into the greased bread moulder for final proving for one hour.

The dough was then baked at $220^{\circ} \mathrm{C}$ for 30 minutes and the bread were cooled and packed.

\section{Chemical constituents of Brown Rice Flour and developed products}

Chemical constituent's viz., moisture, carbohydrate, protein, fat, crude fibre, free fatty acid, peroxide value, thiamine, riboflavin, vitamin E, calcium, iron and phosphorus were analysed. The method of analysis for chemical constituents adopted in the study is given in Table 4 .

\section{Shelf life studies of developed products}

Brown rice flour incorporated cookies were packed in Poly Propylene pouches and plastic containers and stored at ambient condition for a period of 120 days. The stored samples were utilized for quality analysis. 
Sensory quality of brown rice flour incorporated products

The brown rice flour incorporated products were evaluated organoleptically for various quality attributes such as colour, texture, flavour, taste and overall acceptability by a panel of 15 semi trained judges using 9 point hedonic scale (Watts et al., 1989).

\section{Statistical analysis}

The data obtained from two replications $\left(\mathrm{R}_{2}\right.$ and $R_{3}$ ) were subjected to statistical analysis to find out the significant effect of treatments, packaging materials and storage period on the quality of the brown rice varieties during storage. Factorial completely randomized design was applied for the analysis (Gomez and Gomez., 1984).

\section{Results and discussion}

\section{Chemical constituents of brown rice flour}

The chemical constituent of the brown rice flour is presented in table 5 .

\section{Quality analysis of the developed brown} rice cookies

\section{Nutrient content of brown rice cookies}

From table 6, it could be inferred that, as the level of incorporation of the brown rice increased, the nutrient content also indicated significant changes. There was notable increase in the carbohydrate content, but a slight decrease in the protein which may be due to the incorporation of brown rice. On the contrary there was a reduction in the fat content. The crude fiber content, thiamine, calcium, iron and phosphorus had a significant rise as the level of incorporation of brown rice increased. The statistical analysis of the data also indicated that there existed a significant difference in the nutrient content of the samples as the level of incorporation of brown rice increased (Table 7).

\section{Sensory Quality of brown rice cookies}

The table 8 represents that brown rice cookies that had $50 \%$ incorporation of brown rice had obtained the highest score for colour, flavour, texture, taste and overall quality.

\section{Brown rice bread}

\section{Nutrient content of brown rice bread}

From table 9, it could be inferred that, as the level of incorporation of the brown rice increased, the nutrient content also indicated significant changes. There was notable increase in the carbohydrate content, but a slight decrease in the protein which may be due to the incorporation of brown rice. On the contrary there was a reduction in the fat content. The crude fiber content, thiamine, calcium, iron and phosphorus had a significant rise as the level of incorporation of brown rice increased. The statistical analysis of the data also indicated that there existed a significant difference in the nutrient content of the samples as the level of incorporation of brown rice increased (10).

\section{Sensory qualities of brown rice bread}

The table 11 represents that brown rice bread that had $25 \%$ incorporation of brown rice had obtained the highest score for colour, flavour, texture, taste and overall quality.

General appearance, crust and crumb characteristics of bread containing brown rice flour are presented in Table 12. 
Table.1 List of equipments

\begin{tabular}{|c|c|c|}
\hline 1. & Processing equipments & $\begin{array}{l}\text { Satake dehusker (Type THU35A, Satake Engineering Co., } \\
\text { Japan), Satake grain testing mill (TypeM05, Satake } \\
\text { Engineering Co., Japan), Buhler Laboratory Mill } \\
\text { (Model MLV-202, Switzerland) }\end{array}$ \\
\hline 2. & $\begin{array}{l}\text { Dough mixing } \\
\text { equipments }\end{array}$ & $\begin{array}{l}\text { Flour sifter (M/S Sheet Master, CBE), Spiral kneader } \\
\text { (M/S Sheet Master, CBE), Bread moulder (M/S Sheet Master, } \\
\text { CBE) }\end{array}$ \\
\hline 3. & Baking equipments & $\begin{array}{l}\text { Rotary rack oven-Diesel operated (M/S Sheet Master, CBE), } \\
\text { Baking oven (Memmert model 854, Schwabach, West } \\
\text { Germany), Bread slicer (M/S Sheet Master, CBE) }\end{array}$ \\
\hline 4. & Storage commodity & Refrigerator \\
\hline 5. & Texture analyzer & 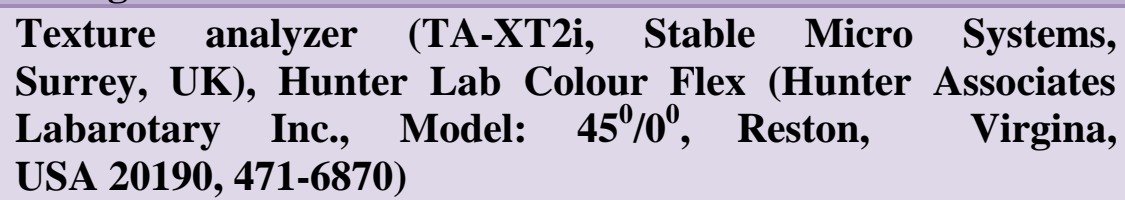 \\
\hline 6. & Packing equipment & Sealing machine (Preethi) \\
\hline 7. & Weighing equipments & $\begin{array}{l}\text { Avery balance ( } 2 \text { kg capacity), Electronic balance (Shimadzu } \\
\text { BL-120-H) }\end{array}$ \\
\hline 8. & Analytical equipments & $\begin{array}{l}\text { Sedimentation shaker (Muhlenbau sedimentation shaker, } \\
\text { Model:189, Peenya Industrial Area, Bangalore, Moisture } \\
\text { meter (Model:RSMA 2, Rajdhani Scientific Instt. Co, New } \\
\text { Delhi), Centrifuge (Universal model:11), Kjeldahl digestion } \\
\text { mantle (Gerhardt), Soxhlet extraction apparatus (Pisces } \\
\text { Instruments, Chennai), Muffle furnance (Gambak make, } \\
\text { UK), Hot air oven (Narang Scientific company, India), U.V } \\
\text { Spectrophotometer (Varian, USA), Spectronic 20 (Bosch and } \\
\text { Lamb, USA), Laminar air flow chamber, Water activity } \\
\text { meter (HygroPalm AW1 (Cole Parmer A-37910-35, } \\
\text { Huntington, New York, USA), Sedimentation shaker } \\
\text { (Muhlenbau sedimentation shaker) }\end{array}$ \\
\hline
\end{tabular}

Table.2 Formulation of brown rice cookies

\begin{tabular}{|l|c|c|c|c|c|}
\hline \multirow{2}{*}{ Ingredient } & Control & \multicolumn{5}{|c|}{ Level of incorporation (\%) } \\
\cline { 2 - 6 } & & $\mathbf{2 5}$ & $\mathbf{5 0}$ & $\mathbf{7 5}$ & $\mathbf{1 0 0}$ \\
\hline Whole wheat flour (g) & 100 & 75 & 50 & 25 & - \\
\hline Brown rice flour (g) & - & 25 & 50 & 75 & 100 \\
\hline Powdered sugar (g) & 30 & 30 & 30 & 30 & 30 \\
\hline Vanaspathi (g) & 50 & 50 & 48 & 48 & 45 \\
\hline Baking powder $(\mathbf{g})$ & 2 & 2 & 2 & 2 & 2 \\
\hline Corn flour $(\mathbf{g})$ & 1 & 1 & 1 & 1 & 1 \\
\hline
\end{tabular}


Table.3 Formulation of brown rice flour bread

\begin{tabular}{|l|c|c|c|c|c|}
\hline \multirow{2}{*}{ Ingredient } & \multirow{2}{*}{ Control } & \multicolumn{4}{c|}{ Level of incorporation (\%) } \\
\cline { 3 - 6 } & & $\mathbf{2 5}$ & $\mathbf{5 0}$ & $\mathbf{7 5}$ & $\mathbf{1 0 0}$ \\
\hline Whole wheat flour (g) & 100 & 75 & 50 & 25 & - \\
\hline Brown rice flour $(\mathbf{g})$ & - & 25 & 50 & 75 & 100 \\
\hline Yeast $(\mathbf{g})$ & 3.0 & 3.0 & 3.0 & 3.0 & 3.0 \\
\hline Salt $(\mathbf{g})$ & 1.5 & 1.5 & 1.5 & 1.5 & 1.5 \\
\hline Sugar $(\mathbf{g})$ & 18 & 18 & 18 & 18 & 18 \\
\hline Calcium propionate $(\mathbf{g})$ & 0.3 & 0.3 & 0.3 & 0.3 & 0.3 \\
\hline Vanaspathi (g) & 2.5 & 2.5 & 2.0 & 2.0 & 1.5 \\
\hline
\end{tabular}

Table.4 Chemical analysis used in the study

\begin{tabular}{|c|c|c|c|c|}
\hline S.No & $\begin{array}{c}\text { Chemical } \\
\text { constituents }\end{array}$ & $\begin{array}{l}\text { Frequency of } \\
\text { analysis }\end{array}$ & Method adopted & Reference \\
\hline 1 & Moisture & Once in 30 days & Hot air oven Method & AOAC (1995) \\
\hline 2. & Starch & Once in 30 days & Anthrone Method & AOAC (1995) \\
\hline 3. & Protein & Once in 30 days & Kjeldahl Method & AOAC (1995) \\
\hline 4. & Free fatty acid & Once in 30days & Titration Method & AOAC (1995) \\
\hline 5. & Fat & 0 day and 180 days & Soxhlet Method & Cohen (1917) \\
\hline 6. & Crude fibre & 0 day and 180 days & $\begin{array}{l}\text { Acid and alkali } \\
\text { titration }\end{array}$ & Maynard, (1970) \\
\hline 7. & Dietary fibre & 0 day and 180 days & Digestion method & AOAC (1995) \\
\hline 8. & Tannin & 0 day and 180 days & Colorimeter & Schandert (1970) \\
\hline 9. & Ash & 0 day and 180 days & Muffle furnace & AOAC (1995) \\
\hline 10. & Calcium & 0 day and 180 days & Titration Method & Clark \& Collip (1925) \\
\hline 11. & Phosphorus & 0 day and 180 days & Titration Method & (Fiske and Subbarow, 1925). \\
\hline 12. & Iron & 0 day and 180 days & $\begin{array}{c}\text { U.V. } \\
\text { Spectrophotometer }\end{array}$ & Wong (1928) \\
\hline
\end{tabular}

Table.5 Chemical constituents of brown rice flour

\begin{tabular}{|r|l|c|}
\hline S. No & Chemical constituents & Value (per 100g) \\
\hline 1. & Moisture $(\mathrm{g})$ & 12.1 \\
\hline 2. & Protein $(\mathrm{g})$ & 8.3 \\
\hline 3. & Carbohydrates $(\mathrm{g})$ & 69.7 \\
\hline $\mathbf{4 .}$ & Fat $(\mathrm{g})$ & 1.6 \\
\hline $\mathbf{5 .}$ & Free fatty acid $(\mathrm{mg} \mathrm{KOH})$ & 2.03 \\
\hline $\mathbf{6 .}$ & Peroxide value $(\mathrm{meq} / \mathrm{kg})$ & 3.09 \\
\hline 7. & Crude fibre $(\mathrm{g})$ & 3.3 \\
\hline
\end{tabular}


Int.J.Curr.Microbiol.App.Sci (2019) 8(7): 1094-1105

Table.6 Nutrient content of brown rice cookies

\begin{tabular}{|l|l|l|l|l|l|l|l|l|}
\hline $\begin{array}{l}\text { Name of the } \\
\text { Product }\end{array}$ & $\begin{array}{l}\text { Moisture } \\
(\mathbf{\%})\end{array}$ & $\begin{array}{l}\text { CHO } \\
\mathbf{( g )}\end{array}$ & $\begin{array}{l}\text { Protein } \\
\mathbf{( g )}\end{array}$ & $\begin{array}{l}\text { Fat } \\
(\mathbf{g})\end{array}$ & $\begin{array}{l}\text { Crude } \\
\text { Fibre } \\
(\mathbf{g})\end{array}$ & $\begin{array}{l}\text { Thiamine } \\
(\mathbf{m g})\end{array}$ & $\begin{array}{l}\text { Calcium } \\
(\mathbf{m g})\end{array}$ & $\begin{array}{l}\text { Iron } \\
(\mathbf{m g})\end{array}$ \\
\hline Control & 12.58 & 66.54 & 13.65 & 20.12 & 0.46 & 0.103 & 17.62 & 1.82 \\
\hline $\begin{array}{l}\text { Cookies } \\
(\mathbf{2 5 \%})\end{array}$ & 12.43 & 69.21 & 11.88 & 19.82 & 0.85 & 0.212 & 18.96 & 1.94 \\
\hline $\begin{array}{l}\text { Cookies } \\
(\mathbf{5 0 \%})\end{array}$ & 12.16 & 71.89 & 10.74 & 19.63 & 1.20 & 0.316 & 20.31 & 2.03 \\
\hline $\begin{array}{l}\text { Cookies } \\
(\mathbf{7 5 \%})\end{array}$ & 12.34 & 74.56 & 9.29 & 19.52 & 1.36 & 0.422 & 21.65 & 2.14 \\
\hline
\end{tabular}

Table.7 Statistical Analysis of brown rice cookies

\begin{tabular}{|c|c|c|c|c|c|c|c|c|c|c|c|c|}
\hline \multirow[t]{2}{*}{ Source } & \multicolumn{3}{|c|}{ Moisture } & \multicolumn{3}{|c|}{ Carbohydrate } & \multicolumn{3}{|c|}{ Protein } & \multicolumn{3}{|c|}{ Fat } \\
\hline & SED & $\begin{array}{c}\text { CD } \\
(0.05)\end{array}$ & $\begin{array}{c}\text { CD } \\
(0.01)\end{array}$ & SED & $\begin{array}{c}\text { CD } \\
(0.05)\end{array}$ & $\begin{array}{c}\text { CD } \\
(0.01)\end{array}$ & SED & $\begin{array}{c}\text { CD } \\
(0.05)\end{array}$ & $\begin{array}{c}\text { CD } \\
(0.01)\end{array}$ & SED & $\begin{array}{c}\text { CD } \\
(0.05)\end{array}$ & $\begin{array}{c}\text { CD } \\
(0.01)\end{array}$ \\
\hline $\mathbf{T}$ & 16 & 0.026 & $0.036 * *$ & 3 & 0.011 & $0.034 * *$ & 6 & 0.012 & $0.016^{* *}$ & .007 & 0.013 & $0.033^{*}$ \\
\hline Sou & \multicolumn{3}{|c|}{ Fibre } & \multicolumn{3}{|c|}{ Calcium } & \multicolumn{3}{|c|}{ Iron } & \multicolumn{3}{|c|}{ Thiamine } \\
\hline & SED & $\begin{array}{c}\text { CD } \\
(0.05)\end{array}$ & $\begin{array}{c}\text { CD } \\
(0.01)\end{array}$ & SED & $\begin{array}{c}\text { CD } \\
(0.05)\end{array}$ & $\begin{array}{c}\text { CD } \\
(0.01)\end{array}$ & SED & $\begin{array}{c}\text { CD } \\
(0.05)\end{array}$ & $\begin{array}{c}\text { CD } \\
(0.01)\end{array}$ & SED & $\begin{array}{c}\text { CD } \\
(0.05)\end{array}$ & $\begin{array}{c}\text { CD } \\
(0.01)\end{array}$ \\
\hline $\mathbf{T}$ & 0.014 & 0.026 & $0.057 * *$ & 0.014 & 0.016 & $0.038 * *$ & 0.008 & 0.015 & $0.028 * *$ & 0.009 & 0.015 & $0.44^{*}$ \\
\hline
\end{tabular}

Table.8 Sensory qualities of the brown rice cookies

\begin{tabular}{|c|c|c|c|c|c|}
\hline \multirow{2}{*}{ Cookies } & \multicolumn{5}{|c|}{ Sensory Attributes } \\
\cline { 2 - 6 } & $\begin{array}{c}\text { Color and } \\
\text { Appearance }\end{array}$ & Flavor & Texture & Taste & $\begin{array}{c}\text { Overall } \\
\text { Acceptability }\end{array}$ \\
\hline Control & $8.1 \pm 0.37$ & $8.6 \pm 0.50$ & $8.5 \pm 0.56$ & $8.5 \pm 0.56$ & $8.6 \pm 0.62$ \\
\hline $\mathbf{2 5}$ & $8.2 \pm 0.40$ & $8.5 \pm 0.50$ & $8.4 \pm 0.49$ & $8.5 \pm 0.50$ & $8.6 \pm 0.49$ \\
\hline $\mathbf{5 0}$ & $8.8 \pm 0.40$ & $8.3 \pm 0.79$ & $8.6 \pm 0.49$ & $7.9 \pm 0.54$ & $8.8 \pm 0.61$ \\
\hline $\mathbf{7 5}$ & $8.1 \pm 0.31$ & $8.4 \pm 0.82$ & $8.5 \pm 0.21$ & $8.7 \pm 0.23$ & $8.2 \pm 0.54$ \\
\hline
\end{tabular}

Values are mean $\pm \mathrm{SD}$

Table.9 Nutrient content of brown rice bread

\begin{tabular}{|l|l|l|l|l|l|l|l|l|}
\hline $\begin{array}{l}\text { Name of the } \\
\text { Product }\end{array}$ & $\begin{array}{l}\text { Moisture } \\
(\mathbf{\%})\end{array}$ & $\begin{array}{l}\text { CHO } \\
(\mathbf{g})\end{array}$ & $\begin{array}{l}\text { Protein } \\
(\mathbf{g})\end{array}$ & $\begin{array}{l}\text { Fat } \\
(\mathbf{g})\end{array}$ & $\begin{array}{l}\text { Crude } \\
\text { Fibre } \\
(\mathbf{g})\end{array}$ & $\begin{array}{l}\text { Thiamine } \\
(\mathbf{m g})\end{array}$ & $\begin{array}{l}\text { Calcium } \\
(\mathbf{m g})\end{array}$ & $\begin{array}{l}\text { Iron } \\
(\mathbf{m g})\end{array}$ \\
\hline Control & 10.75 & 73.78 & 11.26 & 2.86 & 0.86 & 0.284 & 20.61 & 2.24 \\
\hline Bread (25\%) & 12.08 & 74.64 & 10.10 & 2.87 & 1.10 & 0.428 & 21.12 & 2.04 \\
\hline Bread (50\%) & 12.34 & 75.57 & 9.55 & 2.89 & 1.73 & 0.965 & 21.80 & 2.85 \\
\hline $\begin{array}{l}\text { Bread } \\
(\mathbf{7 5 \% )}\end{array}$ & 12.14 & 76.87 & 8.24 & 2.65 & 1.15 & 0.982 & 22.01 & 2.98 \\
\hline
\end{tabular}


Table.10 Statistical analysis of brown rice bread

\begin{tabular}{|c|c|c|c|c|c|c|c|c|c|c|c|c|}
\hline \multirow[b]{2}{*}{ Source } & \multicolumn{3}{|c|}{ Moisture } & \multicolumn{3}{|c|}{ Carbohydrate } & \multicolumn{3}{|c|}{ Protein } & \multicolumn{3}{|c|}{ Fat } \\
\hline & SED & $\begin{array}{l}\text { CD } \\
(0.05)\end{array}$ & $\begin{array}{l}\text { CD } \\
(0.01)\end{array}$ & SED & $\begin{array}{l}\text { CD } \\
(0.05)\end{array}$ & $\begin{array}{l}\text { CD } \\
(0.01)\end{array}$ & SED & $\begin{array}{l}\text { CD } \\
(0.05)\end{array}$ & $\begin{array}{l}\text { CD } \\
(0.01)\end{array}$ & SED & $\begin{array}{l}\text { CD } \\
(0.05)\end{array}$ & $\begin{array}{l}\text { CD } \\
(0.01)\end{array}$ \\
\hline $\mathbf{T}$ & 16 & 0.026 & $0.036 * *$ & & 0.011 & $0.034 * *$ & & 0.012 & $0.016^{* *}$ & 0.007 & 0.013 & $0.033^{*}$ \\
\hline Sou & \multicolumn{3}{|c|}{ Fibre } & \multicolumn{3}{|c|}{ Calcium } & \multicolumn{3}{|c|}{ Iron } & \multicolumn{3}{|c|}{ Thiamine } \\
\hline & SED & $\begin{array}{l}\text { CD } \\
(0.05)\end{array}$ & $\begin{array}{l}\text { CD } \\
(0.01)\end{array}$ & SED & $\begin{array}{l}\text { CD } \\
(0.05)\end{array}$ & $\begin{array}{l}\text { CD } \\
(0.01)\end{array}$ & SED & $\begin{array}{l}\text { CD } \\
(0.05)\end{array}$ & $\begin{array}{l}\text { CD } \\
(0.01)\end{array}$ & SED & $\begin{array}{l}\text { CD } \\
(0.05)\end{array}$ & $\begin{array}{l}\text { CD } \\
(0.01)\end{array}$ \\
\hline $\mathbf{T}$ & 0.014 & 0.026 & $0.057 * *$ & 0.014 & 0.016 & $0.038 * *$ & 0.008 & 0.015 & $0.028 * *$ & 0.009 & 0.015 & $0.44^{*}$ \\
\hline
\end{tabular}

Table.11 Sensory qualities of brown rice bread

\begin{tabular}{|l|l|l|l|l|l|}
\hline \multirow{2}{*}{ Bread } & \multicolumn{5}{|c|}{ Sensory Attributes } \\
\cline { 2 - 6 } & $\begin{array}{l}\text { Color } \\
\text { Appearance }\end{array}$ & Flavor & Texture & Taste & $\begin{array}{l}\text { Overall } \\
\text { Acceptability }\end{array}$ \\
\hline Control & $8.5 \pm 0.68$ & $8.3 \pm 0.65$ & $8.4 \pm 0.49$ & $8.4 \pm 0.67$ & $8.5 \pm 0.50$ \\
\hline $\mathbf{2 5} \%$ & $8.3 \pm 0.44$ & $8.1 \pm 0.37$ & $8.3 \pm 0.54$ & $8.5 \pm 0.50$ & $8.6 \pm 0.46$ \\
\hline $\mathbf{5 0 \%}$ & $8.2 \pm 0.53$ & $8.5 \pm 0.46$ & $8.3 \pm 0.65$ & $8.5 \pm 0.62$ & $8.7 \pm 0.46$ \\
\hline $\mathbf{7 5 \%}$ & $8.1 \pm 0.31$ & $8.4 \pm 0.82$ & $8.5 \pm 0.21$ & $8.7 \pm 0.23$ & $8.2 \pm 0.54$ \\
\hline
\end{tabular}

Values are mean \pm SD

Table.12 Physical characteristics of brown rice bread

\begin{tabular}{|c|c|c|c|c|c|c|c|c|c|}
\hline \multirow[t]{2}{*}{ Bread } & \multicolumn{3}{|c|}{ General appearance } & \multicolumn{2}{|c|}{ Crust characteristic } & \multicolumn{4}{|c|}{ Crumb characteristics } \\
\hline & Evenness & Edge & centre & Colour & consistency & Colour & structure & Texture & Odour \\
\hline Control & Even & Medium & Medium & Light brown & Tender & $\begin{array}{l}\text { White } \\
\text { yellow }\end{array}$ & Fine even & Soft silky & Appetizing \\
\hline $25 \%$ & Even & Medium & Medium & Light brown & Tender & $\begin{array}{l}\text { Slight } \\
\text { yellow }\end{array}$ & Even & Ligh & Good \\
\hline $50 \%$ & Medium even & Low & Low & brownish & Medium tender & Yellowish & Coars & Light silky & Appetizing \\
\hline $75 \%$ & uneven & Too low & low & Deep brown & Medium tender & Yellowish & Coarse even & Light silky & Medium \\
\hline
\end{tabular}

Table.13 Quality parameters of brown rice bread loaves

\begin{tabular}{|c|c|c|}
\hline Bread & $\begin{array}{c}\text { Loaf weight } \\
\text { (g) }\end{array}$ & $\begin{array}{c}\text { Oven spring } \\
\text { (cm) }\end{array}$ \\
\hline Control & $220.04 \pm 0.89$ & $4.70 \pm 0.01$ \\
\hline $\mathbf{2 5 \%}$ & $221.84 \pm 2.23$ & $3.83 \pm 0.06$ \\
\hline $\mathbf{5 0 \%}$ & $226.69 \pm 1.54$ & $3.47 \pm 0.05$ \\
\hline $\mathbf{7 5 \%}$ & $233.24 \pm 2.57$ & $3.34 \pm 0.12$ \\
\hline
\end{tabular}


Table.14 Nutrient changes in the standardized composite cookies during storage (per100g)

\begin{tabular}{|c|c|c|c|c|c|c|c|c|c|c|c|c|c|c|c|c|}
\hline \multirow{3}{*}{ Nutrients } & \multicolumn{4}{|c|}{$\mathbf{T}_{\mathbf{0}}$} & \multicolumn{4}{|c|}{$\mathbf{T}_{1} \mathbf{V}_{1}$} & \multicolumn{4}{|c|}{$\mathbf{T}_{2} \mathbf{V}_{2}$} & \multicolumn{4}{|c|}{$\mathbf{T}_{3} \mathbf{V}_{3}$} \\
\hline & \multicolumn{2}{|c|}{$\mathbf{P}_{1}$} & \multicolumn{2}{|c|}{$\mathbf{P}_{2}$} & \multicolumn{2}{|c|}{$\mathbf{P}_{1}$} & \multicolumn{2}{|c|}{$\mathbf{P}_{2}$} & \multicolumn{2}{|c|}{$\mathbf{P}_{1}$} & \multicolumn{2}{|c|}{$\mathbf{P}_{2}$} & \multicolumn{2}{|c|}{$\mathbf{P}_{1}$} & \multicolumn{2}{|c|}{$\mathbf{P}_{2}$} \\
\hline & Initial & Final & Initial & Final & Initial & Final & Initial & Final & Initial & Final & Initial & Final & Initial & Final & Initial & Final \\
\hline Moisture (g) & 12.58 & 12.72 & 12.58 & 12.65 & 9.13 & 9.35 & 9.13 & 9.21 & 8.24 & 8.36 & 8.24 & 8.31 & 8.25 & 8.34 & 8.25 & 8.30 \\
\hline Carbohydrate (g) & 66.54 & 65.42 & 66.54 & 65.51 & 66.48 & 66.45 & 66.48 & 66.47 & 66.85 & 66.82 & 66.85 & 66.84 & 64.81 & 64.78 & 64.81 & 64.80 \\
\hline Protein (g) & 13.65 & 13.44 & 13.65 & 13.50 & 6.45 & 6.43 & 6.45 & 6.44 & 6.25 & 6.22 & 6.25 & 6.24 & 7.79 & 7.73 & 7.79 & 7.77 \\
\hline Fat (g) & 20.12 & 20.08 & 20.12 & 20.11 & 20.77 & 20.74 & 20.77 & 20.76 & 21.87 & 21.83 & 21.87 & 21.86 & 21.73 & 21.70 & 21.73 & 21.72 \\
\hline Crude Fibre (g) & 0.46 & 0.38 & 0.46 & 0.44 & 3.10 & 3.07 & 3.10 & 3.09 & 2.65 & 2.61 & 2.65 & 2.64 & 2.77 & 2.73 & 2.77 & 2.76 \\
\hline $\operatorname{Ash}(g)$ & 1.00 & 0.79 & 1.00 & 0.86 & 0.92 & 0.83 & 0.92 & 0.88 & 0.90 & 0.87 & 0.90 & 0.89 & 0.98 & 0.92 & 0.98 & 0.96 \\
\hline Calcium (mg) & 17.62 & 17.45 & 17.62 & 17.54 & 19.07 & 19.04 & 19.07 & 19.06 & 15.73 & 15.69 & 15.73 & 15.72 & 20.40 & 20.36 & 20.40 & 20.39 \\
\hline Iron (mg) & 1.83 & 1.79 & 1.83 & 1.82 & 1.51 & 1.47 & 1.51 & 1.50 & 4.03 & 4.00 & 4.03 & 4.02 & 1.86 & 1.83 & 1.86 & 1.85 \\
\hline Tannin (mg) & 43.88 & 43.75 & 43.88 & 43.81 & 47.87 & 47.82 & 47.87 & 47.85 & 45.47 & 45.39 & 45.47 & 45.44 & 45.12 & 45.08 & 45.12 & 45.10 \\
\hline
\end{tabular}

\begin{tabular}{|c|c|c|c|c|c|c|c|c|c|c|c|c|}
\hline \multirow[t]{2}{*}{ Source } & \multicolumn{3}{|c|}{ Moisture } & \multicolumn{3}{|c|}{ Carbohydrate } & \multicolumn{3}{|c|}{ Protein } & \multicolumn{3}{|c|}{ Fat } \\
\hline & SED & $\begin{array}{c}\text { CD } \\
(0.05)\end{array}$ & $\mathrm{CD}(0.01)$ & SED & $\mathrm{CD}(0.05)$ & $\mathrm{CD}(0.01)$ & SED & $\mathrm{CD}(0.05)$ & $\mathrm{CD}(0.01)$ & SED & $\mathrm{CD}(0.05)$ & $\mathrm{CD}(0.01)$ \\
\hline $\mathbf{T}$ & 0.016 & 0.034 & $0.047 * *$ & 0.015 & 0.032 & $0.044 * *$ & 0.017 & 0.036 & $0.050^{* *}$ & 0.012 & 0.026 & $0.036^{* *}$ \\
\hline $\mathbf{P}$ & 0.011 & 0.024 & $0.033^{* *}$ & 0.010 & 0.022 & $0.031 * *$ & 0.012 & 0.025 & $0.035 \mathrm{NS}$ & 0.008 & 0.018 & $0.025 \mathrm{NS}$ \\
\hline $\mathbf{S}$ & 0.011 & 0.024 & $0.033 * *$ & 0.010 & 0.022 & $0.031 * *$ & 0.012 & 0.025 & $0.035^{* *}$ & 0.008 & 0.018 & $0.025^{*}$ \\
\hline TP & 0.022 & 0.048 & $0.046 * *$ & 0.021 & 0.045 & $0.063^{* *}$ & 0.024 & 0.051 & $0.070 \mathrm{NS}$ & 0.017 & 0.037 & $0.051 \mathrm{NS}$ \\
\hline PS & 0.016 & 0.034 & $0.047 * *$ & 0.015 & 0.032 & $0.044 * *$ & 0.017 & 0.036 & $0.050 \mathrm{NS}$ & 0.012 & 0.026 & $0.036 \mathrm{NS}$ \\
\hline TS & 0.022 & 0.048 & $0.046 * *$ & 0.021 & 0.045 & $0.063 * *$ & 0.024 & 0.051 & $0.070 * *$ & 0.017 & 0.037 & $0.051 \mathrm{NS}$ \\
\hline TPS & 0.032 & 0.048 & $0.044 * *$ & 0.030 & 0.064 & $0.089 * *$ & 0.034 & 0.072 & $0.100 * *$ & 0.025 & 0.053 & $0.073 \mathrm{NS}$ \\
\hline
\end{tabular}

\begin{tabular}{|c|c|c|c|c|c|c|c|c|c|c|c|c|c|c|}
\hline \multirow{2}{*}{ Source } & \multicolumn{4}{|c|}{ Fibre } & \multicolumn{3}{c|}{ Calcium } & \multicolumn{3}{c|}{ Iron } & \multicolumn{3}{c|}{ Tannin } \\
\cline { 2 - 16 } & SED & CD 0.05$)$ & CD $(0.01)$ & SED & CD $(0.05)$ & CD $(0.01)$ & SED & CD $(0.05)$ & CD $(0.01)$ & SED & CD $(0.05)$ & CD $(0.01)$ \\
\hline T & 0.008 & 0.018 & $0.025^{* *}$ & 0.014 & 0.031 & $0.043^{* *}$ & 0.009 & 0.019 & $0.027 * *$ & 0.010 & 0.022 & $0.031 * *$ \\
\hline P & 0.006 & 0.013 & $0.018^{* *}$ & 0.010 & 0.022 & $0.030 \mathrm{NS}$ & 0.006 & 0.014 & $0.019 \mathrm{NS}$ & 0.007 & 0.016 & $0.022^{*}$ \\
\hline S & 0.006 & 0.013 & $0.018^{* *}$ & 0.010 & 0.022 & $0.030 * *$ & 0.006 & 0.014 & $0.019 * *$ & 0.007 & 0.016 & $0.022^{* *}$ \\
\hline TP & 0.012 & 0.026 & $0.036 \mathrm{NS}$ & 0.020 & 0.044 & $0.061 \mathrm{NS}$ & 0.013 & 0.028 & $0.038 \mathrm{NS}$ & 0.015 & 0.032 & $0.044 \mathrm{NS}$ \\
\hline PS & 0.008 & 0.018 & $0.025^{* *}$ & 0.014 & 0.031 & $0.043 \mathrm{NS}$ & 0.009 & 0.019 & $0.027 \mathrm{NS}$ & 0.010 & 0.022 & $0.031^{*}$ \\
\hline TS & 0.012 & 0.026 & $0.036 \mathrm{NS}$ & 0.020 & 0.044 & $0.061 * *$ & 0.013 & 0.028 & $0.038 \mathrm{NS}$ & 0.015 & 0.032 & $0.044^{*}$ \\
\hline TPS & 0.017 & 0.037 & $0.051 \mathrm{NS}$ & 0.029 & 0.062 & $0.086 \mathrm{NS}$ & 0.018 & 0.039 & $0.054 \mathrm{NS}$ & 0.021 & 0.045 & $0.062 \mathrm{NS}$ \\
\hline
\end{tabular}


Fig.1 Brown rice cookies
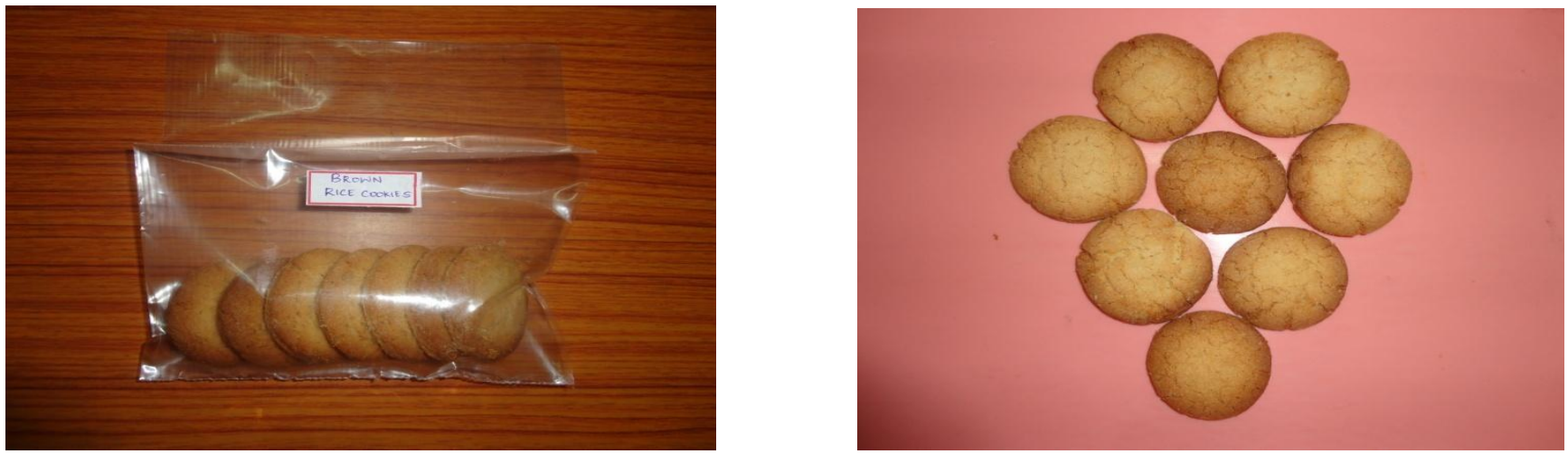

Fig.2 Brown Rice Bread

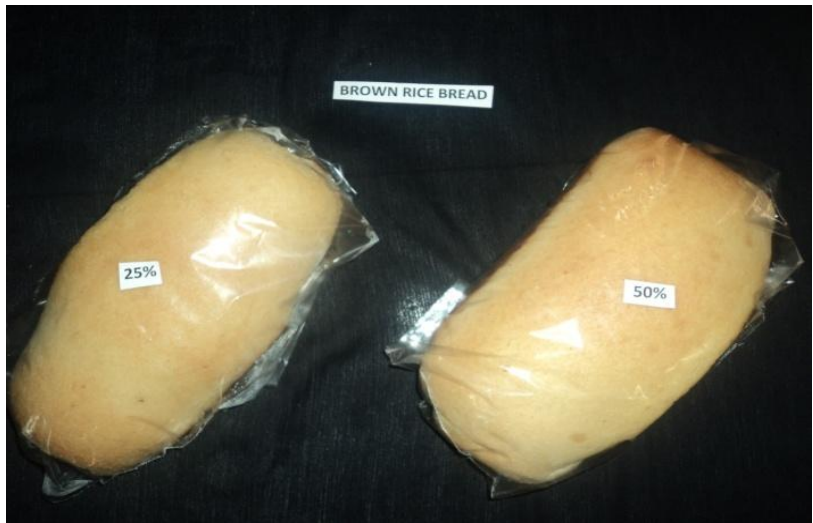

It is observed that control bread had better appearance compared with 25, 50 and $75 \%$ brown rice flour containing bread. The crust colour of the bread containing $75 \%$ brown rice and $50 \%$ brown rice were deeper than those of the control bread and other bread samples. The bread containing $25 \%$ brown rice flour and $50 \%$ brown rice flour had harder crust compared to both the control. The overall crust characteristics of the bread containing $50 \%$ brown rice seemed to be better than other samples. In general, the differences in crust colour between different bread samples become larger as the substitution levels of brown rice flour increased in dough. Colour evaluation was made with interior slices. As a whole, the bread containing $50 \%$ brown rice flour had better crumb colour than those obtained from different levels of brown rice flour. A good

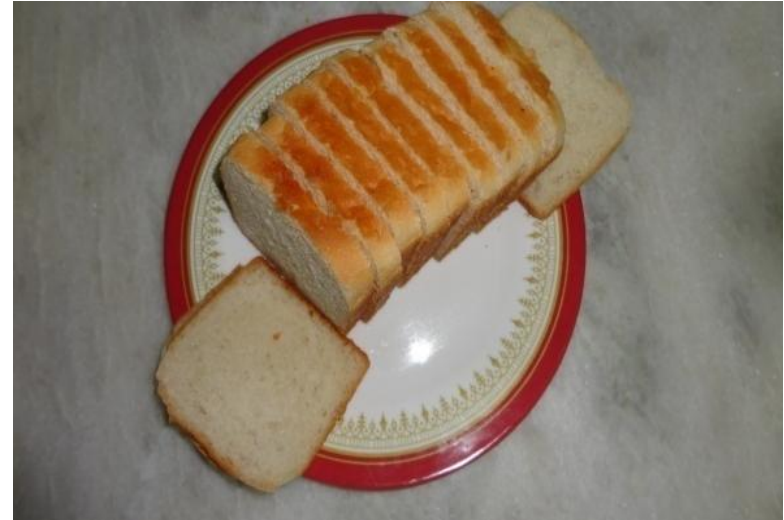

colour regardless of kinds of bread is always desirable. Uniformity of size with thin walled cell is most desirable for crumb grain (Table 13).

\section{Quality parameters of bread loaves}

Table 14 shows the quality parameters of the loaf bread samples. The data shows that by increasing the percentage of brown rice flour in the bread, the formation of the gluten network was reduced.

\section{Shelf life studies of the developed products}

Of the products developed brown rice cookies were more promising and it was taken for shelf life studies. The developed brown rice cookies were kept under ambient condition for shelf life studies for a period of 120 days. 
The changes in the nutrient content during storage are portrayed in Table 15.

From the above table it could be inferred that there was not much changes in the nutrient content of the cookies during storage even after 120 days of storage.

Summary and conclusion are as follows:

Incorporation of brown rice for the development of bakery and extruded products is feasible. Brown rice cookies were developed with the incorporation of $50 \%$ of brown rice to whole wheat flour. The product was nutritional superior by being rich in crude fibre and minerals. The sensory qualities were also highly acceptable. The product had a shelf life of six months, when packed in polypropylene ( 250 gauge thickness). The cost of the brown rice products were cheaper than the control vermicelli, but were on par with millet products. The millet products are already established the premium market, brown rice products are a niche for the premium market. Accordingly a new supply chain for brown rice will be created that is beneficial for growers, processors and consumers.

\section{References}

AOAC. 1995. Official method of Analysis. Association of Official Analytical
Chemists. Arlington, Virginia. USA.

Babu, D., Subhasree, R. S., Bhakyaraj, R. and Vidhyalakshmi, R. 2009. Brown ricebeyond the color reviving a lost health food - a review. American - Eurasian Journal of Agronomy. 2 (2): 67-72.

Begum, M. and Bhattacharyya, R. 2000. Fat contents in raw and cooked Assam rice Varieties. Journal of Food Science and technology. 37 (1):58-60.

Chitra, M., Singh, V. and Ali, S. Z. 2010. Effect of processing paddy on digestibility of rice starch by in Vitro Studies. Journal Food Science Technology. 47(4): 414 - 419.

Clark and Collip, 1925. Estimation of calcium J. Biol. Chem. 63: 641.

Fiske and Subbarao. 1995. Estimation of phosphorus. J. Biological Chem. 66 : 375.

Das, A., Das, S., Subudhi, H., Mishra, P. and Sharma, S. 2012. Extension of shelf life of brown rice with some traditionally available materials. Indian Journal of Traditional Knowledge. 11(3): 553-555.

Gopalan, C., Ramasastri, B.V. and Balsubramaniyan, S.C. 2004. Nutritive value of Indian Foods. National Institute of Nutrition. Hyderabad. India. P. 2050.

Wong, 1928. Estimation of iron. In Oser, B.K. (ed.), Hawk's Physiological Chemistry. 14th Edn. P: 1094.

\section{How to cite this article:}

Gurumeenakshi, G., N. Varadharaju and Rajeswari, R. 2019. Formulation, Development and Evaluation of Bakery Products from Brown Rice. Int.J.Curr.Microbiol.App.Sci. 8(07): 10941105. doi: https://doi.org/10.20546/ijcmas.2019.807.130 